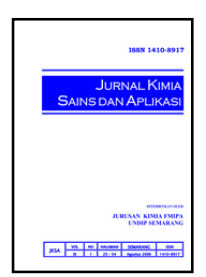

\title{
Pengolahan Limbah Cair Industri Batik dengan Metoda Elektrokoagulasi Menggunakan Besi Bekas Sebagai Elektroda
}

\author{
Titik Darmawanti $^{a}$, Suhartana ${ }^{\mathrm{a}^{*}}$, Didik Setiyo Widodo ${ }^{\mathrm{b}}$ \\ a Inorganic Chemistry Laboratory, Chemistry Department, Faculty of Sciences and Mathematics, Diponegoro University, Jalan Prof. \\ Soedarto, Tembalang, Semarang 50275 \\ b Analytical Chemistry Laboratory, Chemistry Department, Faculty of Sciences and Mathematics, Diponegoro University, Jalan Prof. \\ Soedarto, Tembalang, Semarang 50275 \\ * Corresponding author: suhartana@live.undip.ac.id
}

\begin{tabular}{|c|c|}
\hline Article Info & Abstract \\
\hline & The liquid waste treatment of batik industry by electrocoagulation method using scrap metal \\
\hline $\begin{array}{l}\text { Keywords: } \\
\text { Batik waste, } \\
\text { electrocoagulation, } \\
\text { scrap iron }\end{array}$ & $\begin{array}{l}\text { as electrode has been studied. The study was aimed to separate the dyes of naphthol from } \\
\text { waste. During the electrocoagulation process, the iron metal was able to form } \mathrm{Fe}(\mathrm{OH})_{3} \text { which } \\
\text { acted as a dyestuff adsorbent. Since the } \mathrm{Fe}(\mathrm{OH})_{3} \text { flox could adsorb the naphthol dye hence the } \\
\text { dye can be separated from the waste. In this electrocoagulation process, determination of the } \\
\text { best conditions covered the potential applied, pH variation and electrolysis time. The results } \\
\text { showed that the best-applied potential was obtained at } 5 \text { volts with the best pH of } 2 \text { and } \\
\text { electrolysis time of } 15 \text { minutes. At room temperature, electrocoagulation of batik liquid waste } \\
\text { gave absorbance decrease of } 98.53 \% \text {, while the decrease of COD, TSS and turbidity content } \\
\text { were } 83.64 \%, 99.27 \% \text { and } 98.57 \% \text { respectively. The FTIR data showed the presence of similar } \\
\text { absorption between before and after electrolysis waste. This result suggests that most of the } \\
\text { dyestuffs can be separated from the wastewater and the electrocoagulation method can be } \\
\text { applied to overcome the coloured liquid waste. }\end{array}$ \\
\hline
\end{tabular}

\section{Abstrak}

Kata kunci:

limbah batik, elektrokoagulasi, besi bekas
Telah dilakukan penelitian pengolahan limbah cair industri batik dengan metoda elektrokoagulasi menggunakan besi bekas sebagai elektroda yang bertujuan untuk memisahkan zat warna naftol dari limbah. Selama proses elektrokoagulasi logam besi mampu membentuk $\mathrm{Fe}(\mathrm{OH})_{3}$ yang berperan sebagai adsorben zat warna, karena floks $\mathrm{Fe}(\mathrm{OH})_{3}$ mampu mengadsorpsi zat warna naftol sehingga zat warna dapat dipisahkan dari limbah. Pada proses elektrokoagulasi dilakukan penentuan kondisi terbaik yang meliputi potensial aplikasi, variasi $\mathrm{pH}$ dan waktu elektrolisis. Hasil penelitian menunjukkan bahwa diperoleh potensial aplikasi sebesar 5 volt dengan pH terbaik 2 dengan waktu elektrolisis selama 15 menit. Pada temperatur kamar, elektrokoagulasi limbah cair batik memberikan penurunan absorbansi sebesar 98,53\%, sedangkan penurunan kandungan COD, TSS dan kekeruhan masing-masing adalah 83,64\%, 99,27\% dan 98,57\%. Data FTIR menunjukkan adanya kemiripan serapan yang muncul antara limbah sebelum elektrolisis dan endapan hasil elektrolisis. Hal ini menunjukkan bahwa sebagian besar zat warna telah dapat dipisahkan dari limbah cair dan metoda ektrokoagulasi dapat diaplikasikan untuk mengatasi limbah cair berwarna.

\section{Pendahuluan}

Zat warna banyak digunakan dalam berbagai industri. Industri batik perumahan merupakan salah satu industri yang banyak menggunakan zat warna yang sisanya dibuang ke lingkungan sebagai limbah. Buangan proses pewarnaan batik ini menimbulkan dampak yang merugikan lingkungan, karena lingkungan mempunyai kemampuan terbatas untuk mendegradasi zat warna 
tersebut [1]. Zat warna merupakan senyawa organik yang mengandung gugus kromofor. Zat warna reaktif merupakan zat warna yang banyak digunakan untuk pewarnaan tekstil maupun batik. Pada pewarnaan batik menggunakan pewarna alam juga menggunakan pewarna buatan, misalnya senyawa naftol yang sangat berbahaya. Naftol merupakan salah satu zat warna yang banyak digunakan [2].

Limbah cair dari proses pewarnaan dan pencelupan batik merupakan salah satu sumber pencemaran air yang cukup tinggi jika tidak dilakukan pengolahan limbah. Teknologi pengolahan limbah cair secara biologi, kimia, fisika maupun kombinasi antara ketiga proses tersebut dapat digunakan untuk mengolah limbah cair industri batik. Pengolahan limbah cair dengan proses biologi misalnya dengan menggunakan mikroorganisme juga banyak diterapkan untuk mereduksi senyawa organik limbah cair industri batik [3]. Namun efisiensi penghilangan warna melalui proses biologi ini sering tidak memuaskan, karena zat warna mempunyai sifat tahan terhadap degradasi biologi. Secara fisika dengan adsorpsi menggunakan karbon aktif, silika, dan biomaterial [4]. Penggunaan karbon aktif untuk menghilangkan warna juga memerlukan biaya yang cukup tinggi karena harga karbon aktif relatif mahal. Untuk mengatasi masalah pengolahan limbah cair diperlukan alternatif baru untuk mengolah limbah cair industri batik yang efektif dan efisien dalam menurunkan polutan organik dan zat warna [5].

Di samping itu, lingkungan sekitar kita terdapat berbagai logam bekas seperti besi yang sudah tidak terpakai sehingga dapat mencemari lingkungan. Besi merupakan salah satu logam yang banyak digunakan dalam segala bidang kehidupan manusia, namun setelah tidak terpakai maka besi tersebut akan menjadi bahan pencemar karena besi sulit terdegradasi dan usaha pemanfaatan kembali masih kurang. Sementara itu menurut Cotton $d k k$. [6] besi memiliki sifat sebagai pengoksidasi dengan potensial standar reduksi bernilai positif. Logam besi mampu membentuk gelatin $\mathrm{Fe}(\mathrm{OH})_{3}$ yang mempunyai pori-pori sehingga dapat digunakan untuk mengkoagulasi zat warna [7]. Besi (III) hidroksida biasa digunakan sebagai koagulan dalam pengolahan limbah cair. Besi hidroksida tersebut akan mengadsorpsi pada permukaan zat warna cair dari dalam larutan. Pada penelitian-penelitian sebelumnya telah banyak dilakukan elektrokoagulasi dengan memanfaatkan daya adsorpsi hidroksida besi dan larutan zat warna. Penelitian tersebut antara lain elektrodekolorisasi fenolftalein [8], metal orange [9] dan indigo [10].

Bersumber dari penyebab permasalahan lingkungan dan berdasar penelitian-penelitian sebelumnya, maka diperlukan penelitian tentang elektrokoagulasi zat warna naftol dengan menggunakan logam besi bekas sebagai elektroda. Pengolahan limbah cair industri batik melalui proses elektrokoagulasi dengan menggunakan besi bekas sebagi elektroda dapat mengurangi pencemaran lingkungan yang disebabkan oleh zat warna naftol dan logam bekas, sehingga akan diperoleh limbah cair industri batik yang layak untuk dibuang ke lingkungan. Metode pengurangan zat warna naftol pada limbah industri batik dengan menggunakan elektrokoagulasi ini mempunyai kelebihan dibandingkan metode lainnya, yaitu waktu proses yang lebih singkat, sehingga menghemat proses pengolahan limbah serta tidak membutuhkan proses analisis yang rumit. Selain itu, hasil penelitian ini juga dapat memberikan informasi mengenai penggunaan besi bekas terhadap proses elektrokoagulasi zat warna naftol supaya proses penanganan limbah dapat terjadi secara efektif dan efisien.

\section{Metodologi}

\section{Penentuan Rentang Potensial Aplikasi}

Sel elektrolisis dengan elektroda besi disiapkan. Selanjutnya sebanyak $50 \mathrm{~mL}$ limbah cair batik dimasukkan ke dalam gelas beker, kemudian ditambah 0,71 gram $\mathrm{Na}_{2} \mathrm{SO}_{4}$ dan ditambah $\mathrm{H}_{2} \mathrm{SO}_{4} 0,05 \mathrm{~N}$ sampai $\mathrm{pH}$ menjadi 2. Selanjutnya dipindahkan ke dalam sel elektrolisis kemudian larutan dielektrolisis dengan variasi potensial listrik 1-10 volt selama 20 detik disertai pengukuran arus (I) yang dihasilkan. Perlakuan yang sama dilakukan terhadap larutan blanko, kemudian dari data yang didapat dibuat kurva potensial listrik terhadap arus listrik (E terhadap $i$ ) untuk memperoleh daerah kerja elektrolisis dan potensial minimal untuk mengelektrolisis sampel pada suasana asam.

Daerah potensial aplikasi untuk kondisi basa dapat dicari dengan perlakuan yang sama seperti pada kondisi asam tetapi dengan menambahkan $\mathrm{NaOH} 0,05 \mathrm{~N}$ sampai pH 10. Selanjutnya potensial aplikasi yang diperoleh dari suasana asam dan basa dibandingkan dan ditentukan potensial aplikasinya.

Elektrokoagulasi Limbah Cair Batik dengan Variasi pH dan Waktu

Selanjutnya sebanyak $50 \mathrm{~mL}$ limbah cair batik dimasukkan ke dalam gelas beker, kemudian ditambah 0,71 gram $\mathrm{Na}_{2} \mathrm{SO}_{4}$ dan ditambah $\mathrm{H}_{2} \mathrm{SO}_{4} 0,05 \mathrm{~N}$ sampai $\mathrm{pH}$ menjadi 2. Selanjutnya dipindahkan ke dalam sel elektrolisis yang dihubungkan dengan potensial listrik luar selama 20 menit. Perlakuan tersebut diulang untuk variasi $\mathrm{pH}$ 4, 6, 8, 10 dan 12 dengan menambahkan asam sulfat 0,05 $\mathrm{N}$ dan atau $\mathrm{NaOH} 0,05 \mathrm{~N}$. Perlakuan tersebut diulang untuk variasi lama elektrolisis 10, 15, 20, 25 dan 30 menit. Setelah dilakukan pengujian, maka diperoleh waktu minimum proses elektrolisis.

\section{Elektrokoagulasi Limbah Cair Industri Batik pada Kondisi Terbaik}

Sel elektrolisis dengan elektroda besi bekas disiapkan sebanyak 8 pasang. Kemudian dipasang pada rangkaian alat seperti pada desain alat. Selanjutnya sebanyak 1 liter limbah cair industri batik ditambah 14,2 gram $\mathrm{Na}_{2} \mathrm{SO}_{4}$ dan ditambah $\mathrm{H}_{2} \mathrm{SO}_{4}$ 0,05 $\mathrm{N}$ sampai $\mathrm{pH}$ menjadi 2. Kemudian masing-masing elektroda dihubungkan dengan potensial listrik luar pada potensial aplikasi sebesar 5 volt selama 15 menit. Filtrat yang diperoleh dilakukan pengujian dan endapan yang terbentuk dilakukan analisis dengan menggunakan FTIR. 
Penentuan Persentase Dekolorisasi Pewarna Naftol dalam Limbah Cair Industri Batik dengan Spektrofotometer

Absorbansi tiap limbah cair industri batik sebelum dan sesudah elektolisis dengan berbagai konsentrasi pada panjang gelombang maksimum. Persentase dekolorisasi didapat dari absorbansi larutan sebelum elektrolisis dikurangi absorbansi larutan setelah elektrolisis dan dibagi absorbansi sebelum elektrolisis lalu dikali $100 \%$.

$$
\text { Persentase Dekolorisasi }=\frac{\Delta A}{A o} \times 100 \%
$$

$\Delta A=$ Perubahan absorbansi yaitu absorbansi awal absorbansi akhir

Ao = absorbansi awal

\section{Uji Kadar COD}

Sampel limbah sebanyak $2 \mathrm{~mL}$ dan ditambahkan 1 mL larutan pendestruksi serta $2 \mathrm{ml}$ larutan $\mathrm{H}_{2} \mathrm{SO}_{4}$ dan direfluks pada suhu $150^{\circ} \mathrm{C}$ selama 2 jam. Kemudian penyiapan 5 larutan standar KHP 0, 50,100,150, 200 ppm dengan volum yang sama. Selanjutnya dilakukan pembacaan absorbansi pada panjang gelombang $600 \mathrm{~nm}$ dan pembuatan kurva kalibrasi. Kemudian dilakukan pengukuran sampel dan larutan standar pada panjang gelombang $600 \mathrm{~nm}$. Pengukuran dilakukan dengan analisis duplo.

\section{Uji Kekeruhan}

Pengukuran kadar kekeruhan dilakukan dengan menggunakan alat Nefelometer. Kadar kekeruhan dihitung dengan cara mengalikan nilai kekeruhan yang diperoleh dengan faktor pengenceran.

\section{Pengujian Padatan Tersuspensi Total}

Air limbah batik diaduk dengan magnetic stirer untuk memperoleh air limbah batik yang homogen. Kemudian $100 \mathrm{~mL}$ limbah batik disaring menggunakan kertas saring yang sebelumnya telah dikeringkan di dalam oven dan dikeringkan di dalam desikator. Kertas saring yang berisi padatan tersuspensi dipindahkan ke dalam botol timbang dan dimasukkan ke dalam oven selama 2 jam pada suhu $103^{\circ} \mathrm{C}-105^{\circ} \mathrm{C}$. Setelah selesai dikeringkan selanjutnya dinginkan ke dalam desikator selama 1 jam untuk menyeimbangkan suhu dan ditimbang.

$$
\text { Kadar Padatan Tersuspensi Total }(\mathrm{mg} / \mathrm{L})=\frac{(A-B)}{V_{\text {contoh } u j i L}} \times 1000
$$

Keterangan: $A$ = berat kertas saring dengan residu kering (mg). $B$ = berat kertas saring (mg)

\section{Hasil dan Pembahasan}

Penelitian pengolahan limbah cair batik dengan metode elektrokoagulasi menggunakan besi bekas sebagai elektroda ini bertujuan untuk mengurangi intensitas warna naftol dalam limbah cair batik dengan terlebih dahulu mencari kondisi terbaik yang meliputi penentuan potensial aplikasi, $\mathrm{pH}$ dan waktu elektrolisis.
Desain sel elektrolisis pada penentuan kondisi terbaik terdiri atas wadah gelas, elektroda kerja (besi bekas) sebagai anoda dan katoda. Elektrolisis juga dikerjakan pada skala 1 liter limbah dengan proses pengolahan seperti pada desain alat.

Metode elektrolisis digunakan untuk mengurangi intensitas warna naftol dalam limbah cair batik karena dalam proses elektrolisis besi sebagai anoda akan dihasilkan $\mathrm{Fe}(\mathrm{OH})_{3}$ yang berupa endapan yang mampu memflokulasi pewarna melalui kopresipitasi dan penambahan elektrolit maka besi lebih aktif dan lebih banyak teroksidasi. Jarak antarelektroda dibuat $1 \mathrm{~cm}$ dengan maksud agar gas hidrogen yang dihasilkan oleh katoda selama proses elektrolisis dapat mengenai permukaan anoda secara lebih merata sehingga dapat mempercepat proses pengapungan dan pengumpulan flok-flok besi hidroksida yang dihasilkan selama proses elektrolisis. Semakin besar jarak elektroda semakin besar pula hambatan yang timbul bagi reaksi yang sedang berlangsung. Hal ini sesuai dengan persamaan $R=\rho \frac{l}{A}$, jika luas penampang elektroda $(A)$ dibuat konstan, maka semakin kecil jarak antar elektroda (l) semakin kecil pula hambatan $(R)$ yang timbul dalam reaksi pada sistem elektrolisis tersebut. Sesuai hukum Ohm: $I=\frac{V}{R}$, pada potensial atau tegangan konstan, semakin kecil hambatan yang timbul, maka arus menjadi semakin besar sehingga mengakibatkan proses oksidasi yang terjadi semakin cepat. Semakin cepat proses oksidasi maka pembentukan flok besi hidroksida juga semakin cepat. Di samping hal di atas, temperatur juga merupakan salah satu faktor yang dapat mempengaruhi proses elektrolisis, dalam penelitian ini temperatur yang digunakan adalah temperatur kamar (lingkungan) yang dianggap konstan.

\section{Efek Kelistrikan}

Metode pengurangan intensitas warna pada limbah cair batik secara elektrolisis dengan elektroda besi dapat terjadi karena dalam sistem elektrolisis tersebut terjadi reaksi reduksi-oksidasi. Pada anoda terjadi proses oksidasi yaitu besi teroksidasi menghasilkan kation besi $\left(\mathrm{Fe}^{2+}\right)$, sedangkan pada katoda terjadi reaksi reduksi air menghasilkan gas hidrogen dan anion hidroksida $\left(\mathrm{OH}^{-}\right)$.

Reaksi reduksidan oksidasi yang terjadi dalam sistem elektrolisis tersebut mengakibatkan terjadinya flokulasi yaitu terbentuknya flok besi hidroksida yang berupa endapan gelatin berwarna hijau. Flok yang terbentuk ini mampu mengadsorpsi pewarna naftol melalui proses kopresipitasi. Harga potensial reaksi total yang terjadi bernilai negatif. Berdasarkan persamaan: $\Delta G=-n . F . E_{\text {sel }}$, maka harga perubahan energi bebas gibbs $(\Delta G)$ bernilai positif sehingga reaksi tidak dapat berlangsung secara spontan. Untuk dapat terjadinya reaksi agar elektrokoagulasi dapat berlangsung maka perlu diberikan potensial atau tegangan diberikan [11].

Reaksi redoks yang terjadi dalam sistem elektrolisis memenuhi persamaan berikut: 


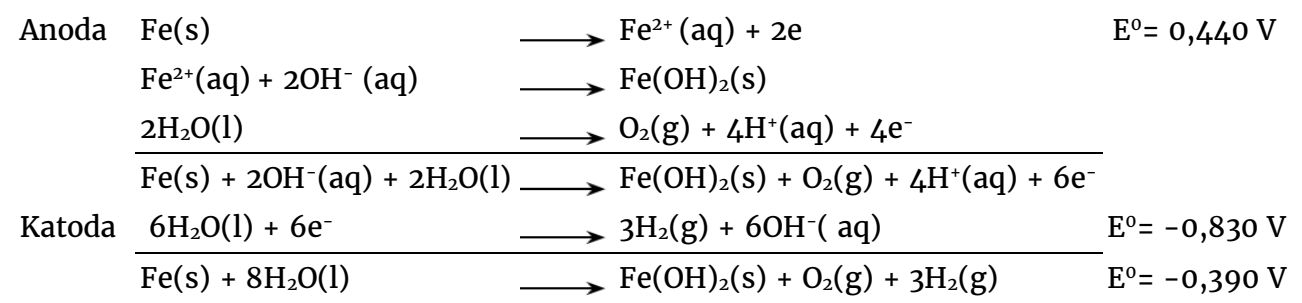

Adanya oksigen terlarut dan oksigen hasil elektrolisis menyebabkan ferro hidroksida teroksidasi menjadi ferri hidroksida [11].

\begin{tabular}{llll} 
Anoda: & $4 \mathrm{Fe}(\mathrm{s})$ & & \\
& $4 \mathrm{Fe}^{2+}(\mathrm{aq})+10 \mathrm{H}_{2} \mathrm{O}(\mathrm{l})+\mathrm{O}_{2}(\mathrm{~g})(\mathrm{aq})+8 \mathrm{e}^{-}$ \\
Katoda: & $\longrightarrow$ & $4 \mathrm{Fe}(\mathrm{OH})_{3}(\mathrm{~s})+8 \mathrm{H}^{+}(\mathrm{aq})$ \\
& $8 \mathrm{H}^{+}(\mathrm{aq})+8 \mathrm{e}^{-}$ & & $4 \mathrm{H}_{2}(\mathrm{~g})$ \\
\cline { 2 - 3 } & $4 \mathrm{Fe}_{(\mathrm{s})}+10 \mathrm{H}_{2} \mathrm{O}(\mathrm{l})+\mathrm{O}_{2}(\mathrm{~g})$ & $\longrightarrow$ & $4 \mathrm{Fe}(\mathrm{OH})_{3}(\mathrm{~s})+4 \mathrm{H}_{2}(\mathrm{~g})$
\end{tabular}

\section{Elektrolisis Pelarut dan Penentuan Potensial Aplikasi}

Elektrolisis pelarut dikerjakan dengan melakukan variasi potensial selama elektrolisis berlangsung. Arus yang mengalir di dalam sistem elektrolisis pada potensial tertentu dicatat dan digambarkan sebagai kurva potensial terhadap arus. Kurva ini memberikan informasi tentang ranah elektroaktif sistem pelarut berair pada $\mathrm{pH}$ tertentu (asam dan basa). Sistem ini terdiri atas akuades dan elektrolit pendukung $\left(\mathrm{Na}_{2} \mathrm{SO}_{4}\right)$ tempat elektroda besi tercelup. Rentang potensial ini menggambarkan tingkat energi yang setara dengan energi yang diperlukan untuk berlangsungnya proses transfer elektron. Besar dan lebar rentang potensial ini bersifat khusus untuk setiap pelarut dan dalam penerapannya bergantung pula pada komposisi sistem elektrolit pendukung dan sifat alami elektroda aplikasi besi. Rentang potensial ini memberikan batas terbesar pemberian potensial pada tahap elektrolisis selanjutnya. Hal tersebut bertujuan supaya kajian elektrolisis tidak diganggu dengan komplikasi reaksi yang bisa terjadi pada daerah potensial yang lebih besar [12]. Penentuan rentang potensial dekomposisi ini dilakukan pada kondisi asam yang diwakili oleh $\mathrm{pH} 2$ dan kondisi basa yang diwakili oleh $\mathrm{pH} 10$.

Elektrolisis limbah cair batik dikerjakan pada harga potensial yang masuk dalam ranah elektroaktif pelarut akuades. Elektrolisis yang dilakukan di luar daerah ini akan mengakibatkan pelarut yang digunakan ikut terelektrolisis sehingga mekanisme elektrokimia yang dikaji menjadi bertambah rumit karena adanya kompetisi dan campur tangan reaksi kimia produk/spesies kimia yang terbentuk selama proses elektrolisis pelarut (sebagaimana dijelaskan pada bagian atas subbab ini).

Gambar 1 dan 2 memberikan informasi rentang potensial elektrolisis dan potensial aplikasi terendah yang harus diberikan untuk proses elektrolisis selanjutnya. Untuk sistem elektrolisis dengan elektroda besi pada suasana asam diperoleh rentang potensial sebesar 3,8-5,47 volt sedangkan untuk suasana basa diperoleh rentang potensial 3,55-6,13 volt. Selanjutnya potensial aplikasi untuk elektroda besi ditetapkan sebesar 5 volt baik pada suasana asam maupun basa.

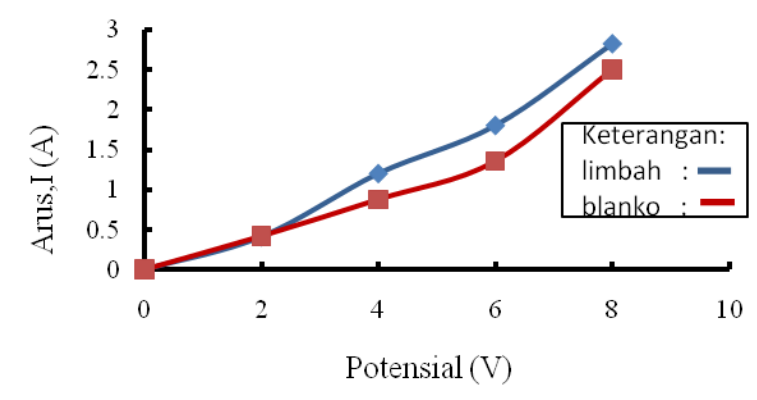

Gambar 1 Kurva hubungan antara arus dan potensial aplikasi dalam elektrolisis limbah dan larutan blanko pada $\mathrm{pH} 2$ (asam)

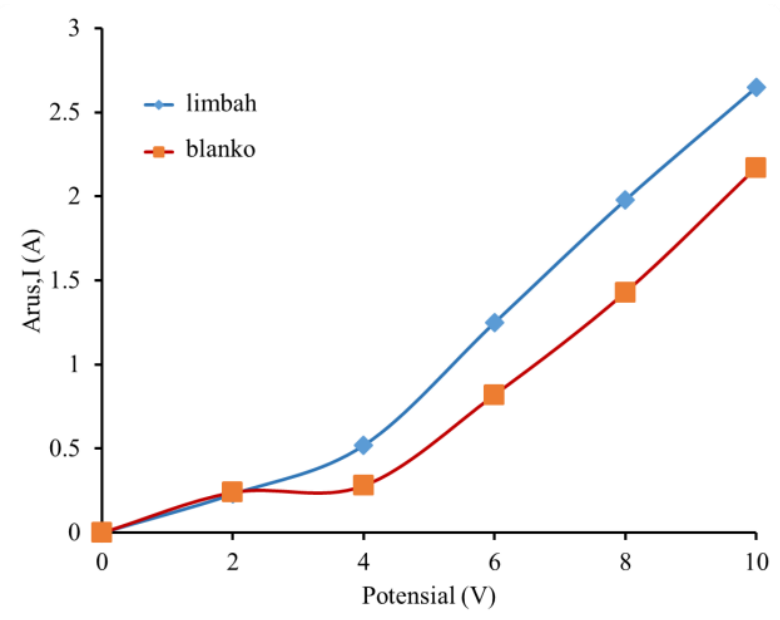

Gambar 2. Kurva hubungan antara arus dan potensial aplikasi dalam elektrolisis limbah dan larutan blanko pada $\mathrm{pH} 10$ (basa)

\section{Pengaruh $\mathrm{pH}$ pada Elektrolisis}

Untuk menentukan kondisi pH elektrolisis limbah cair batik, dilakukan elektrolisis pada potensial terkontrol dengan variasi $\mathrm{pH}$ dan absorbansi sebagai parameter yang diukur. Elektrolisis dilakukan dengan menggunakan elektroda besi dengan variasi $\mathrm{pH} \mathrm{2,} \mathrm{4,} \mathrm{6,}$ 8, 10 dan 12. Dari data yang didapat kemudian digambarkan sebagai kurva $\mathrm{pH}$ terhadap persentase dekolorisasi. 


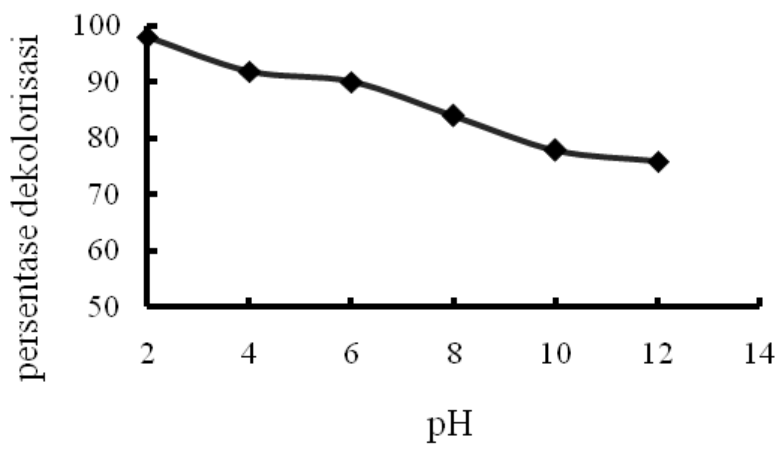

Gambar 3. Kurva hubungan antara pH dengan persentase dekolorisasi

Kurva ini memberikan informasi hubungan antara pH dengan persentase dekolorisasi limbah. Kecenderungan $\mathrm{pH}$ yang diperoleh akan digunakan sebagai parameter tetap pada proses elektrokoagulasi limbah cair batik. Pada penelitian ini persentase dekolorisasi lebih tinggi pada suasana asam dan ditetapkan $\mathrm{pH}$ yang digunakan untuk elektrolisis limbah yaitu pada $\mathrm{pH} 2$ dengan persentase dekolorisasi paling tinggi yaitu sebesar $98,09 \%$. Persentase dekolorisasi limbah cair batik pada $\mathrm{pH}$ asam ini dapat terjadi dikarenakan oleh dua hal yaitu, pertama besi lebih mudah teroksidasi pada suasana asam dibanding basa, sehingga dengan waktu yang sama produksi besi hidroksida yang dihasilkan pada suasana asam akan lebih banyak dibandingkan pada suasana basa. Kedua pada suasana asam ion-ion hidrogen lebih mudah terserap oleh endapan gel besi hidroksida, sehingga mengakibatkan besi hidroksida semakin bermuatan positif, akibatnya partikel-pertikel bermuatan netral dan cenderung negatif seperti halnya naftol akan mudah terkopresipitasi pada suasana asam dibandingkan pada suasana basa, pada suasana basa yang akan terserap oleh besi hidroksida tersebut adalah ion-ion hidroksida sehingga muatan endapan tersebut menjadi negatif akibatnya sulit bagi naftol untuk dapat terkopresipitasi oleh besi hidroksida tersebut.

\section{Penentuan Waktu Elektrolisis}

Untuk menentukan waktu elektrolisis dekolorisasi limbah cair batik, dilakukan elektrolisis pada potensial terkontrol dengan variasi waktu elektrolisis dan absorbansi sebagai parameter yang diukur. Elektrolisis dilakukan dengan menggunakan elektroda besi dengan variasi waktu elektrolisis 5, 10, 15, 20, 25 dan 30 menit. Data yang diperoleh kemudian digambarkan sebagai kurva waktu elektrolisis terhadap persentase dekolorisasi.

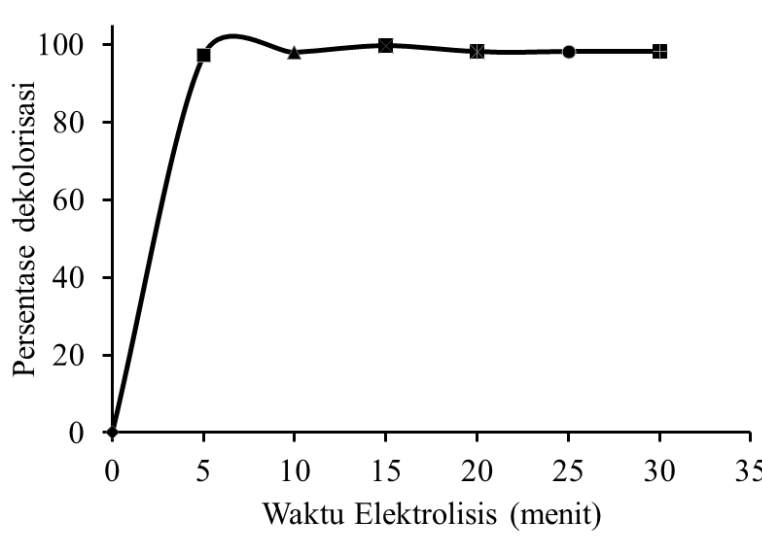

Gambar 4. Kurva hubungan antara waktu elektrolisis dengan persentase dekolorisasi limbah cair pada potensial 5 volt

Kurva ini memberikan informasi hubungan antara waktu elektrolisis dengan persentase dekolorisasi limbah. Kecenderungan waktu yang diperoleh akan digunakan sebagai parameter tetap pada proses elektrokoagulasi limbah cair batik skala 1 liter. Sesuai dengan hukum Farraday: $W=\frac{e \cdot i \cdot t}{96500}$, maka dengan peningkatan waktu maka berat endapan yang diperoleh akan semakin besar. Hal ini menunjukkan bahwa semakin lama waktu elektrolisis maka floks besi (III) hidroksida yang terbentuk semakin besar karena ion besi yang terbentuk semakin banyak dan zat warna yang terkoagulasi juga akan semakin banyak. Pada penelitian ini pada $\mathrm{pH} 2$ diperoleh waktu elektrolisis selama 15 menit dengan persentase dekolorisasi $99,69 \%$. Setelah melebihi waktu minimal maka persentase dekolorisasi cenderung tetap.

\section{Mekanisme Dekolorisasi}

Elektrokoagulasi zat warna naftol dalam limbah cair tekstil dapat terjadi karena ada proses adsorpsi. Adsorpsi terjadi karena adanya proses kopresipitasi zat warna naftol dalam endapan gel besi hidroksida. Besi hidroksida ini akan tersuspensi membentuk koloid berupa partikel besar dan stabil, lalu partikel tersebut mengendap sebagai endapan. Pada proses pembentukan endapan tersebut besi hidroksida akan mengkopresipitasi pewarna yang ada dalam limbah, karena adanya interaksi antara besi hidroksida dengan pewarna tersebut. Besi hidroksida di sini adalah senyawa elektrolit biner yang bermuatan positif dan negatif. Partikel tersebut berinteraksi dengan zat warna melalui interaksi elektrostatik atau pengompleksan permukaan akibat terkoagulasi sehingga flok hidroksida besi-zat warna yang selanjutnya terflokulasi membentuk floks-floks yang mempunyai ukuran lebih besar dan akhirnya mengendap.

Penggunaan metode elektrolisis untuk menghasilkan adsorben besi hidroksida yang lebih digambarkan sebagai $\mathrm{Fe}_{2} \mathrm{O}_{3} \cdot \mathrm{xH}_{2} \mathrm{O}$ diasumsikan lebih efektif daripada dengan pemberian koagulan yang sama. Hal tersebut karena $\mathrm{Fe}$ yang teroksidasi belum sepenuhnya berikatan dengan ion hidroksida dalam larutan dan sebagai kation polivalen yang masih mampu 
berinteraksi dengan anion-anion maupun molekul netral yang ada disekitarnya. Struktur rongga $\mathrm{Fe}_{2} \mathrm{O}_{3} \cdot \mathrm{xH}_{2} \mathrm{O}$ berupa floks coklat kemerahan yang terfloatasi di permukaan. Untuk mengimbangi gayagaya di bagian dalam maka molekul-molekul naftol dan zat warna lain menjadi tertarik ke permukaan floks, gaya ini relatif lemah (van der walls). Flok $\mathrm{Fe}(\mathrm{OH})_{3}$ yang terbentuk masih aktif sebagai inti floks yang akan mengkopresipitasi (membawa serta atau mengendapkan) zat warna kemudian terfloatasi di permukaan dan bergabung membentuk molekul yang lebih besar sehingga akan mengendap dan dapat dipisahkan dari larutan dengan penyaringan [9].

Terjadinya kopresipitasi zat warna naftol dengan besi (III) hidroksida ditunjukkan oleh adanya kemiripan puncak-puncak spektra FTIR endapan limbah hasil elektrokoagulasi dengan puncak-puncak spektra limbah sebelum dielektrokoagulasi yang ditunjukkan oleh gambar 5-6:

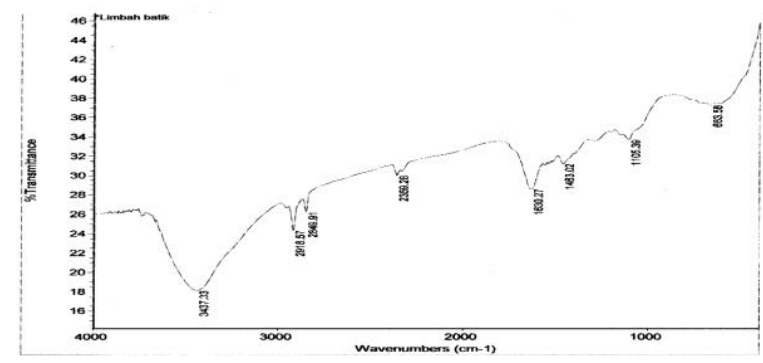

Gambar 5. Spektra FTIR limbah batik sebelum elektrokoagulasi

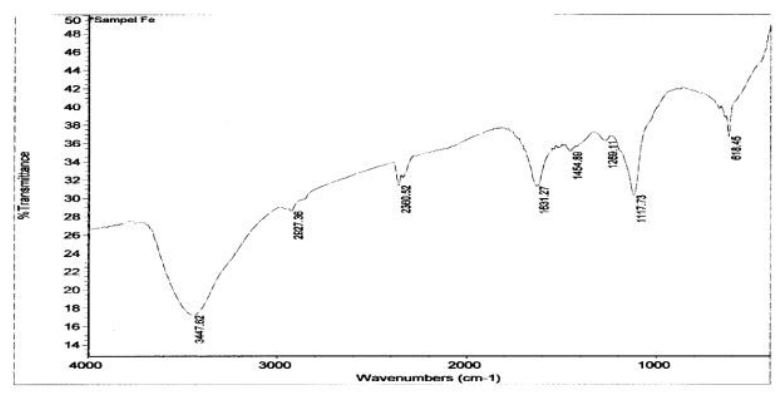

Gambar 6. Spektra FTIR residu elektrokoagulasi

Pada gambar 5 terlihat bahwa spektra FTIR limbah batik sebelum pengolahan menunjukkan adanya serapan dengan puncak melebar pada $3437,33 \mathrm{~cm}^{-1}$ yang menunjukkan adanya gugus $\mathrm{OH}$ alkohol. Adanya serapan $\mathrm{C}-\mathrm{O}$ pada bilangan gelombang $1105,39 \mathrm{~cm}^{-1}$ juga memperkuat adanya gugus $\mathrm{OH}$ yang terikat pada rantai karbon. Adanya puncak serapan lemah pada 1463,02 $\mathrm{cm}^{-}$ ${ }^{1}$ menunjukkan adanya $\mathrm{C}=\mathrm{C}$, dalam hal ini $\mathrm{C}=\mathrm{C}$ berada sebagai sistem dalam senyawa aromatik. Puncak serapan ini diperkuat dengan adanya puncak serapan lain pada $1630,27 \mathrm{~cm}^{-1}$ yang merupakan konjugasi ikatan rangkap dengan fenil yang mampu menggeser puncak serapan $\mathrm{C}=\mathrm{C}$.

Pada gambar 6 dapat dilihat spektra FTIR endapan elektrolisis diasumsikan bahwa zat warna naftol telah berikatan dengan flok $\mathrm{Fe}(\mathrm{OH})_{3}$, hal ini dapat ditunjukkan oleh adanya serapan dengan puncak melebar pada
$3447,62 \mathrm{~cm}^{-1}$ yang menunjukkan adanya gugus $\mathrm{OH}$ alkohol. Adanya serapan $\mathrm{C}-\mathrm{O}$ pada bilangan gelombang $1117,73 \mathrm{~cm}^{-1}$ juga memperkuat adanya gugus $\mathrm{OH}$ yang terikat pada rantai karbon. Adanya puncak serapan lemah pada $1454,89 \mathrm{~cm}^{-1}$ menunjukkan adanya $\mathrm{C}=\mathrm{C}$, dalam hal ini $\mathrm{C}=\mathrm{C}$ berada sebagai sistem dalam senyawa aromatik. Puncak serapan ini diperkuat dengan adanya puncak serapan lain pada $1631,27 \mathrm{~cm}^{-1}$ yang merupakan konjugasi ikatan rangkap dengan fenil yang mampu menggeser puncak serapan $\mathrm{C}=\mathrm{C}$. Dengan adanya kemiripan spektra FTIR antara limbah sebelum pengolahan dengan residu hasil elektrolisis, maka dapat disimpulkan bahwa sebagian besar zat warna telah dapat dipisahkan dari limbah cair melalui proses elektrokoagulasi.

Di samping melalui mekanisme koagulasi, proses dekolorisasi limbah batik dimungkinkan terjadi karena struktur molekul naftol telah rusak selama proses elektrolisis. Pada proses ini elektroda besi juga berperan sebagai elektroda biasa yang merupakan tempat oksidasi berlangsung. Untuk mendukung asumsi ini, dilakukan pembandingan proses elektrolisis dengan bahan elektroda yang tidak membentuk flok, seperti karbon. Pada elektrolisis limbah cair batik dengan elektroda karbon menyebabkan penurunan absorbansi dari 0,848 menjadi 0,345 atau dengan persentase dekolorisasi sebesar 59,3\%, karbon yang digunakan sebagai elektroda di anoda dan katoda bersifat inert sehingga tidak bereaksi dengan reaktan, produk dan elektrolit, maka floks yang diinginkan juga tidak terbentuk. Penurunan absorbansi terjadi karena proses degradasi zat warna yang dimungkinkan karena adanya kerusakan ikatan-ikatan pada gugus dalam struktur senyawa naftol.

\section{Elektrokoagulasi Limbah Cair Berdasarkan Kondisi Terbaik}

Setelah diketahui kondisi terbaik elektrolisis yang meliputi potensial 5 volt, $\mathrm{pH} 2$ selama 15 menit maka dilakukan elektrokoagulasi limbah cair dalam skala 1 liter dengan 8 elektroda yang disusun paralel menggunakan satu sumber tegangan listrik. Setelah dilakukan elektrolisis maka limbah disaring untuk memisahkan filtrat dan residunya, kemudian dilakukan analisis baik kualitatif maupun kuantutatif. Analisis kualitatif yang dilakukan antara lain $\mathrm{pH}$, perubahan warna larutan dan endapan yang diperoleh. Analisis kuantitatif yang dilakukan antara lain penentuan persentase dekolorisasi, kadar COD, TSS dan kekeruhan. Hasil yang diperoleh dapat dilihat pada tabel dibawah ini.

Tabel 1. Perbandingan kualitas limbah sebelum dan sesudah elektrolisis skala 1 liter

\begin{tabular}{cccc}
\hline Parameter & $\begin{array}{c}\text { Sebelum } \\
\text { proses }\end{array}$ & $\begin{array}{c}\text { Setelah } \\
\text { proses }\end{array}$ & $\begin{array}{c}\text { Persentase } \\
\text { penurunan }\end{array}$ \\
\hline Derajat keasaman (pH) & 7.33 & 6,19 & - \\
Kekeruhan (mg/L) & 146,50 & 2,1 & 98,57 \\
COD (mg/L) & 9969,5 & 1631,3 & 83,64 \\
TSS (mg/L) & 138 & 1,0 & 99,28 \\
Warna (absorbansi) & 0,848 & 0.0125 & 98,53 \\
\hline
\end{tabular}


Dari tabel di atas dapat dilihat bahwa terjadi penurunan kandungan COD, TSS, kekeruhan dan warna. Kekeruhan dan TSS dapat diturunkan hingga 98,57\% dan $99,28 \%$ karena zat warna dan senyawa kimia yang lain mampu dipisahkan dari limbah sehingga limbah hasil elektrolisis menjadi jernih. Kadar COD mampu diturunkan hingga 83,64\% karena sebagian besar senyawa organik termasuk zat warna dapat dipisahkan dari limbah, ada yang teradsorpsi oleh floks dan sebagian strukturnya telah rusak akibat teroksidasi. Hal ini juga ditandai dengan penurunan warna dari berwarna merah keruh menjadi bening dengan penurunan zat warna persentase dekolorisasi) sebesar $98,53 \%$.

Spektra kualitatif UV-Vis untuk limbah cair sebelum elektrolisis seperti disajikan gambar 7 menunjukkan adanya puncak pada panjang gelombang $485 \mathrm{~nm}$ (panjang gelombang maksimum $485 \mathrm{~nm}$ ) yang disebabkan oleh warna dari senyawa (terutama naftol) yang berada dalam limbah cair tersebut. Spektra kualitatif UV-Vis untuk limbah cair yang telah dielektrolisis dengan elektroda besi seperti disajikan gambar 8 memperlihatkan bahwa tidak ada puncak serapan pada daerah panjang gelombang 400-600 nm sehingga dapat disimpulkan bahwa zat warna naftol telah mampu dipisahkan dari limbah.

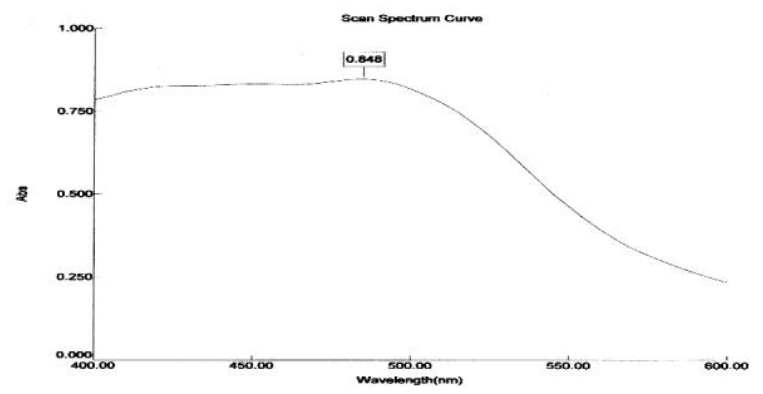

Gambar 7. Spektra UV-Vis limbah cair sebelum elektrolisis

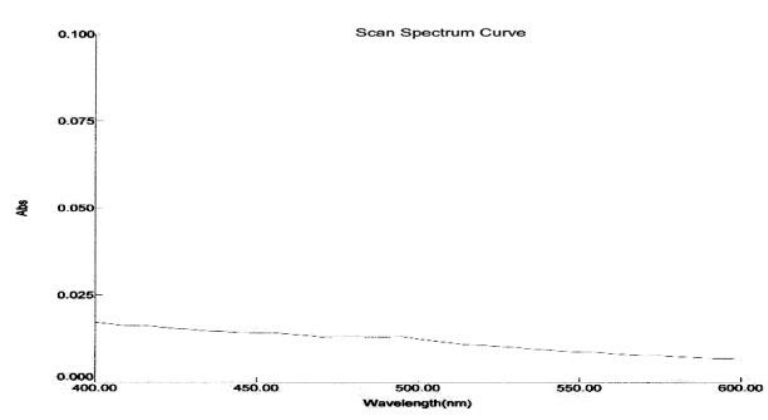

Gambar 8 Spektra UV-Vis limbah cair setelah elektrolisis

Dengan melihat berbagai hasil di atas dapat disimpulkan bahwa elektrokoagulasi menggunakan besi sebagai elektroda untuk kasus-kasus zat warna dapat diaplikasikan.

\section{Kesimpulan}

Zat warna naftol dalam limbah cair industri batik dapat dipisahkan dengan metode elektrokoagulasi menggunakan elektroda besi. Kondisi terbaik elekrokoagulasi limbah cair batik elektroda besi yaitu pada potensial aplikasi 5 volt, $\mathrm{pH}$ 2, dan waktu elektrolisis minimal 15 menit. Pada kondisi tersebut ini diperoleh persentase dekolorisasi $98,53 \%$, penurunan COD 83,64\%, kekeruhan 98,57 \%, dan TSS 99,28\% dalam skala limbah satu liter.

\section{Daftar Pustaka}

[1] Daniela Suteu, Doina Bilba, Equilibrium and kinetic study of reactive dye Brilliant Red HE-3B adsorption by activated charcoal, Acta Chimica Slovenica, 52, 1, (2005) 73-79

[2] Manaskorn Rachakornkij, Sirawan Ruangchuay, Sumate Teachakulwiroj, Removal of reactive dyes from aqueous solution using bagasse fly ash, Songklanakarin Journal of Science and Technology, $26,1,(2004) 13-24$

[3] M. Ali Mazmanci, Ali Ünyayar, Decolourisation of Reactive Black 5 by Funalia trogii immobilised on Luffa cylindrica sponge, Process Biochemistry, 40,

$$
\begin{array}{lll}
1, & \text { (2005) 337-342 }
\end{array}
$$

http://dx.doi.org/10.1016/j.procbio.2004.01.007

[4] S. Mondal, Methods of Dye Removal from Dye House Effluent-An Overview, Environmental Engineering Science, $\quad 25, \quad 3, \quad$ (2008) 383-396 http://dx.doi.org/10.1089/ees.2007.0049

[5] Renita Manurung, Rosdanelli Hasibuan, Irvan, Zat Warna Azo Reaktif Secara Aerob dan Anaerob, in, Jurusan Teknik Kimia, Universitas Sumatera Utara, Medan, 2004.

[6] Frank Albert Cotton, Geoffrey Wilkinson, Paul L. Gaus, Basic inorganic chemistry, John Wiley, 1995.

[7] Arthur Israel Vogel, G. Svehla, Textbook of Macro and Semimicro Qualitative Inorganic Analysis, Longman Scientific \& Technical, 1987.

[8] Joko Kristanto, Laju elektrodekolorisasi Phenolptalein sebagai fungsi Voltase, in: Jurusan Kimia, Universitas Diponegoro, Semarang, 2000.

[9] Famila Dwi Ningsih Dekolorisasi Metil Orange menggunakan Anoda Besi, in: Jurusan Kimia, Universitas Diponegoro, Semarang, 2000.

[10] Aciep Dwi Hadiyanto, Pengaruh pH dan Penambahan Hidrogen Peroksida terhadap Elektrorisasi Pewarna Indigo, in: Jurusan Kimia, Universitas Diponegoro, Semarang, 2003.

[11] Philip Henri Rieger, Electrochemistry, Springer Netherlands, 1994.

[12] Didik Setiyo Widodo Widodo, Gunawan, Wahyu Adi Kristanto, Elektroremediasi Perairan Tercemar: Penggunaan Grafit pada Elektrodekolorisasi Larutan Remazol Black B, Jurnal Kimia Sains dan Aplikasi, 11, 2, (2008) 34-37 